\title{
TRADISI NIROK-NANGGOK MASYARAKAT BELITUNG: SEJARAH DAN KAIDAH MATEMATIS
}

\author{
Fiki Alghadari \\ STKIP Kusuma Negara Jakarta \\ alghar6450@gmail.com
}

\begin{abstract}
ABSTRAK
Penelitian ini bertujuan untuk mengkaji sejarah dan kaidah matematis pada tradisi niroknanggok di pulau Belitung. Nirok-nanggok adalah upacara adat yang menunjukan rasa syukur, dilakukan beramai-ramai, dan dipandu oleh seorang pemimpin. Tujuan penulisan artikel ini adalah untuk mengetahui kaidah matematis apa yang tersirat dalam tradisi nirok-nanggok, dan bagaimana kontekstual kaidah matematis dalam tradisi nirok-nanggok tersebut. Studi ini dipandang sebagai salah satu bentuk nyata bahwa dalam tradisi tidak semata-mata hanya menonjolkan adat istiadat dan norma saja, namun dengan sudut pandang tertentu dapat dijadikan bahasan bahwa suatu tradisi telah terkonsep secara matematis. Tradisi budaya daerah yang memuat kaidah matematis ini dapat dijadikan sebagai salah satu contoh kontekstual dalam belajar matematika. Berdasarkan hasil kajian, disimpulkan bahwa kaidah matematis yang tersirat dalam tradisi nirok-nanggok adalah teori peluang. Kontekstual budaya nirok-nanggok dicontohkan sesuai dengan konsep peluang kejadian independen, peluang kejadian bersyarat, dan frekuensi harapan. Kaidah peluang merupakan teori prediksi dan bukan suatu kepastian, sehingga suatu kejadian yang diprediksi merupakan kejadian yang mungkin akan terjadi dan mungkin juga tidak terjadi.
\end{abstract}

Kata Kunci : Kaidah Matematis, Nirok-Nanggok, Teori Peluang.

\section{PENDAHULUAN}

Setiap daerah pasti memiliki ciri khas tersendiri. Kebudayaan dan adat istiadat merupakan ciri khas masing-masing daerah. Kebudayaan dan adat harus terus dilestarikan (Triwardani \& Rochayanti, 2014; Rachman, 2012). Contoh akibat kurang melestarikan kebudayaan adalah telah terjadi klaim negara lain terhadap budaya atau tradisi lokal daerah Indonesia. Kasus ini menyebabkan pemerintah Indonesia mengambil langkah cepat dalam usaha menjaga keanekaragaman budaya daerah melalui pelestarian budaya (Nisafani, dkk., 2014). Usaha pelestarian salah satunya bertujuan agar mendapat perhatian Negara-negara di dunia, yang akan memberi dampak positif bagi daerah setempat. Contohnya, tradisi batik telah mendapat pengakuan dunia yang dikukuhkan oleh United Nations Educational, Scientific and Cultural Organization (UNESCO) sebagai salah satu hasil budaya asli indonesia pada bulan Oktober 2009 di Perancis.

Termasuk salah satu usaha melestarikan budaya, bidang pendidikan sebagai ujung tombak pelaku yang terhimpun melalui kegiatan kesiswaan dan pembelajaran. Pendidikan 
lahir dari budaya dan selanjutnya budaya semakin berkembang di lingkup pendidikan karena pendidikan menyebabkan terjadinya beragam perubahan pada bidang sosial budaya. Lingkup pendidikan tersebut tidak terlepas pada pembelajaran di sekolah, namun prosesnya juga merupakan alur pembudayaan yang formal atau proses akulturasi dan dapat menjadi sarana utama pengenalan beragam budaya yang kemudian dapat diadopsi dan dilestarikan (Atmaja, 2014; Ubayanti, dkk., 2016; Rachman, 2012). Jadi budaya dan pendidikan adalah sesuatu yang berbeda dan sangat sulit dipisahkan.

Dalam konteks pendidikan dan makna filosofisnya, budaya daerah tidak terlepas dari kaidah matematis (Atmaja, 2014). Sejarah mencatat bahwa lahirnya matematika karena budaya, atau ada juga yang mengatakan sebaliknya. Budaya adalah embrio dari lahirnya konsep matematis. Matematika merupakan produk budaya hasil abstraksi pikiran manusia sehiingga matematika adalah konstruksi budaya manusia (Rakhmawati, 2016; Ubayanti, dkk., 2016), yang tidak lain adalah aktivitas kedaerahan yang diwariskan secara turun temurun (Ubayanti, dkk., 2016; Tandililing, 2016; Rachman, 2012).

Setiap suku yang hidup di suatu tempat atau peradaban, mengembangkan matematika menurut pandangan dan corak kehidupannya (Ubayanti, dkk., 2016). Inilah yang dinamakan ethnomatematika, yaitu realitas hubungan antara budaya lingkungan manusia dan matematika (Atmaja, 2014). Etnomatematika didefinisikan sebagai cara-cara khusus suatu kelompok budaya atau masyarakat tertentu dalam beraktivitas, yang aktivitasnya memuat kaidah matematis. Lebih lanjut, aktivitas yang dimaksud merupakan aktivitas yang memuat proses abstraksi pengalaman nyata dalam kehidupan sehari-hari sehingga menghasilkan karya sebagai peninggalan budaya (Rakhmawati, 2016; Tandililing, 2016; Ubayanti, dkk., 2016).

Budaya merupakan warisan leluhur yang menjadi ciri khas setiap daerah (Rachman, 2012). Nyatanya, berbagai keanekaragaman budaya daerah telah menjadikan Indonesia sebagai salah satu pemilik yang kaya akan manfaat dan sumber daya (Prambudi, 2010; Tandililing, 2016; Triwardani \& Rochayanti, 2014). Kondisi geografis Indonesia yang memiliki ribuan pulau dan tersebar dari Sabang sampai Marauke menjadi faktor mula kemunculannya (Ubayanti, dkk., 2016; Nisafani, dkk., 2014). Sumbangsih leluhur kreatif kepada cucu-cucunya untuk dieksplorasi sedemikian rupa dan sebaik-baiknya, serta dapat dijadikan modal untuk melanjutkan kehidupan sosial maupun ekonomi kemasyarakatan (Triwardani \& Rochayanti, 2014; Rachman, 2012). Dengan demikian, aktivitas dan kreatifitas para leluhur bangsa Indonesia bukan tidak berhubungan dengan konsep 
matematis dan tidak memiliki sejarah matematika. Tetapi, aktivitas para leluhur tidak terekspose dalam media informasi dan komunikasi secara global maupun universal.

Selain tidak terekspose, aktivitas bermatematika leluhur juga tidak tercatat. Buktinya sampai sekarang belum ada temuan manuskrip kuno layaknya bangsa-bangsa yang menjadi kiblat peradaban seperti suku Babilonia, bangsa Yunani, Persia, atau lainnya. Referensi matematika yang berkembang sampai saat ini masih menggunakan referensi di luar peradaban Indonesia. Bukan berarti aktivitas leluhur bangsa Indonesia selalu tidak didasarkan kaidah matematis, tetapi semua aktivitas matematis yang dilakukannya telah terintegrasi lansung dalam pengalaman lapangan tanpa ada kajian tertulis (Tandililing, 2016). Bukti nyata hasil aktivitas matematis leluhur Indonesia dapat dilihat pada peninggalan budaya seperti arsitektur candi yang dibangun simetris (Rachman, 2012).

Kaidah matematis telah menjadi unsur khusus perkembangan budaya pada suatu kalangan masyarakat. Namun masyarakatnya sendiri jarang menyadari implementasi hal tersebut (Atmaja, 2014; Rakhmawati, 2016; Ubayanti, dkk., 2016; Tandililing, 2016). Padahal, konsep matematis yang tersirat dalam tradisi budaya telah sering dimanfaatkan dalam beraktivitas. Dengan demikian dapat dikatakan bahwa keberadaan tradisi budaya merupakan salah satu bentuk realisasi konsep matematis, termasuk tradisi budaya di Pulau Belitung, Bangka Belitung, Indonesia.

Di Belitung ada tradisi budaya yang memuat kajian etnomatematika. Salah satunya tradisi nirok-nanggok. Bentuk kajian etnomatematika mencakup segala bidang seperti arsitektur, pertanian, kesenian daerah, atau yang lainnya (Atmaja, 2014; Tandililing, 2016; Prambudi, 2010; Triwardani \& Rochayanti, 2014). Tradisi nirok-nanggok mencakup kajian etnomatematika di bidang spiritual. Tujuan penulisan artikel ini difokuskan untuk mengetahui kaidah matematis apa yang tersirat dalam tradisi tersebut dan bagaimana kontekstual kaidah matematisnya.

\section{HASIL DAN PEMBAHASAN}

\section{Sejarah Pulau Belitung dan Tradisi Nirok-Nanggok}

Belitung adalah sebuah pulau kecil yang terletak di sebelah barat laut pulau Jawa yang dipisahkan Laut Jawa, sebelah barat daya pulau Kalimantan yang dipisahkan Selat Karimata, dan sebelah tenggara pulau Sumatra yang dipisahkan Selat Bangka. Belitung adalah daerah provinsi Bangka Belitung. Antara pulau Belitung dan pulau Bangka terpisah oleh selat Gaspar (Wikipedia, 2017). Daerah yang menjadi rebutan residen Inggris dan 
koloni Belanda ini menjadi bagian Negara Kesatuan Republik Indonesia (NKRI) setelah kemerdekaan diproklamirkan tanggal 17 Agustus 1945 di Jakarta, namun sistem pemerintahan masih memakai sistem distrik bentukan Belanda. Setelah bergabung dengan NKRI, status Bangka Belitung terdegradasi menjadi Kabupaten, karena Peraturan Pengganti Undang-undang No.3/1956 menghapuskan status Keresidenan dan melalui Undang-undang Darurat No.4 Tahun 1956, Bangka Belitung digabungkan menjadi bagian dari Provinsi Sumatra Selatan (Prambudi, 2010; "Pulau Belitung," 2017). Tetapi setelah tahun 2000, Pulau Belitung dan Pulau Bangka bersama-sama digabung membentuk provinsi baru, dengan nama Bangka Belitung, ibukotanya Pangkal Pinang. Mulanya, Belitung hanya terdiri dari satu kabupaten, akan tetapi sejak berlakunya otonomi daerah, tahun 2003 kabupaten Belitung terbagi menjadi Belitung dan Belitung Timur ("Pulau Belitung," 2017).

Menurut beberapa versi cerita legenda, nama pulau yang konon merupakan bagian semenanjung utara pulau Bali yang terputus hanyut ini berasal dari nama raja Jawa yaitu Belitung Uttunggade atau Rake Watakura Dyah Belitung. Pada abad XV, muncul suatu peradaban di Belitung yaitu dimulai dengan berdirinya kerajaan Badau oleh bangsawan majapahit dipimpin raja yang bernama Datuk Mayang Geresik. Pada abad XVII, Kerajaan Badau ditaklukkan oleh Kerajaan Balok rintisan bangsawan Majapahit yang lain yang bernama Ronggo Udo (Adjin, dkk. 2014; Prambudi, 2010; “Pulau Belitung,” 2017).

Bermula dari kemunculan kerajaan Balok di Belitung bahwa diyakini menjadi pusat peradaban dan perkembangan budaya masyarakat melayu. Kebudayaan melayu mencakup adat istiadat, ritual, pengobatan tradisional, kesenian, peralatan dan senjata, mata pencaharian, arsitektur, bahasa dan sastra, kerajaan, tokoh, hukum adat, dan konsep-konsep yang berkenaan dengan pandangan hidup (Rachman, 2012). Bergulirnya sejarah dimulai dari daerah tempat kerajaan tersebut, sehingga menghasilkan suatu tradisi. Kebudayaan merupakan sistem terintegrasi di masyarakat yang berkaitan dengan nilai, kepercayaan, dan prilaku (Tandililing, 2016). Suatu budaya atau tradisi di Belitung adalah nirok-nanggok (Heru, 2011). Asal mula tradisi nirok-nanggok ini bagian peninggalan situs raja Balok.

Nirok-nanggok adalah kegiatan mengambil ikan di sungai yang dilakukan secara berkelompok. Biasanya kegiatan ini hanya dilakukan oleh masyarakat pedesaan dan telah menjadi rutinitas setelah musim kemarau tiba. Rutinitas masyarakat pedesaan ini sampai sekarang masih terus terlaksana setiap tahun pada musim kemarau panjang antara bulan Agustus dan September, di daerah yang sekarang dinamakan Belantu, Desa Kembiri, 
Membalong, bagian Selatan Pulau Belitung. Di daerah ini memiliki banyak aliran air tawar yang lebar dan pasang, sehingga pada musim kemarau banyak sungai-sungai dan rawa menjadi surut, airnya tidak bisa mengalir, dan di dalam air sungai yang tergenang menyimpan banyak jenis spesies ikan air tawar. Salah satu nama sungai yang biasa dijadikan tempat acara tradisi adalah sungai balok. Daerah Belantu adalah tempat berdirinya kerajaan Balok (Heru, 2011).

Nama tradisi nirok-nanggok berasal dari nama alat yang digunakan yaitu Tirok dan Tanggok. Tirok adalah semacam tongkat kayu, kira-kira berdiameter satu centimeter, ukuran panjang bervariasi sekitar dua sampai empat meter, di bagian pangkal dipasang mata tombak dari logam, biasanya besi putih yang runcing dan tajam (Heru, 2011). Berikut ini disajikan gambaran acara tradisi nirok masyarakat pulau Belitung (Bamboe, 2011).

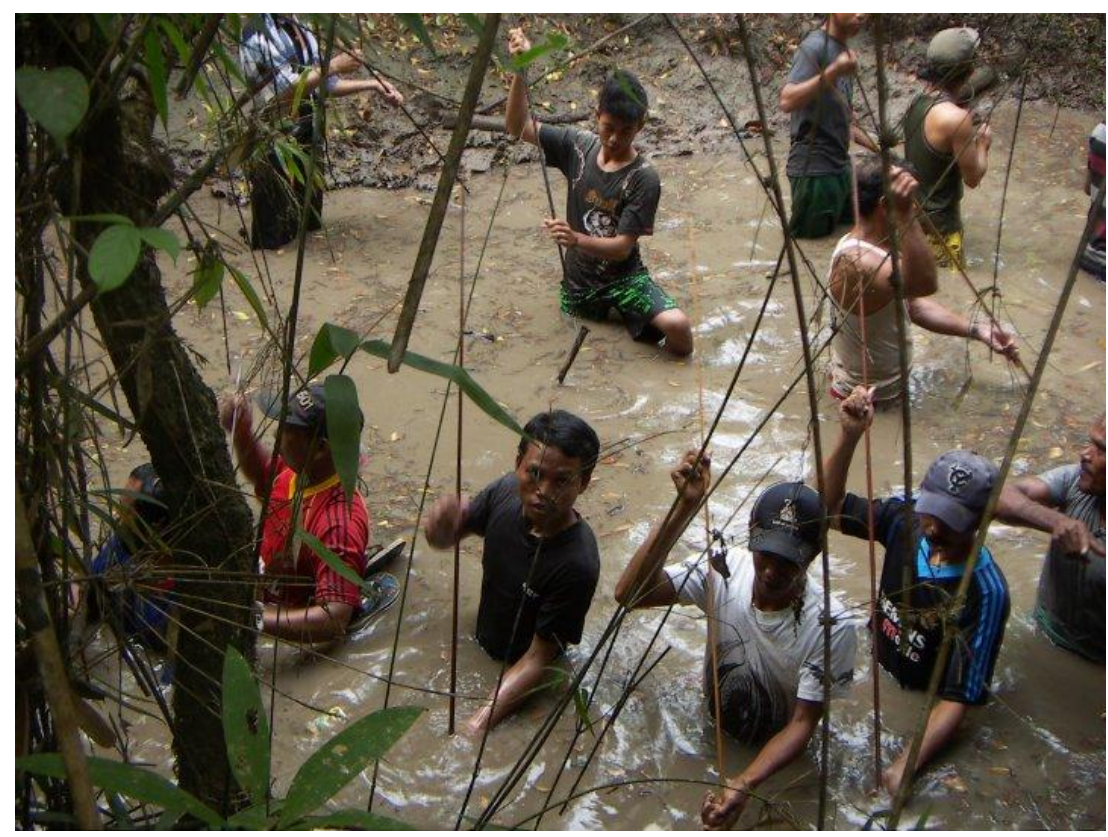

Gambar 1. Tradisi nirok masyarakat Pulau Belitung

Sedangkan tanggok adalah semacam raga atau alat sejenis jala terbuat dari rotan yang dijalin dan tersusun rapi, berukuran kecil dan bergagang lengkung, memiliki kegunaan untuk menangkap/menjaring ikan. Tanggok bentuk lainnya yaitu menggunakan jaring dipasang pada bingkai rotan yang dibentuk persegi panjang (Heru, 2011). Berikut ini disajikan gambar 2, yaitu gambaran kegiatan tradisi masyarakat pedesaan yang sedang menangkap ikan menggunakan tanggok (Edgina, 2015).

Acara tradisi ini merupakan acara yang sakral, sehingga pada pelaksanaannya dimulai dengan tahapan yang cukup panjang beserta aturan-aturan tertentu yang harus 
dipatuhi. Prosesi tradisi ini dipimpin oleh seorang dukun air daerah setempat dan disaksikan pemuka kampung dan seluruh penduduk setempat. Fungsi acara ini adalah menumbuhkan kekompakkan dan mempertebal kepatuhan warga pada adat karena warga hanya mengambil ikan untuk kebutuhan dalam sajian makan bersama, dan tidak pula melakukan eksploitasi secara besar-besaran.

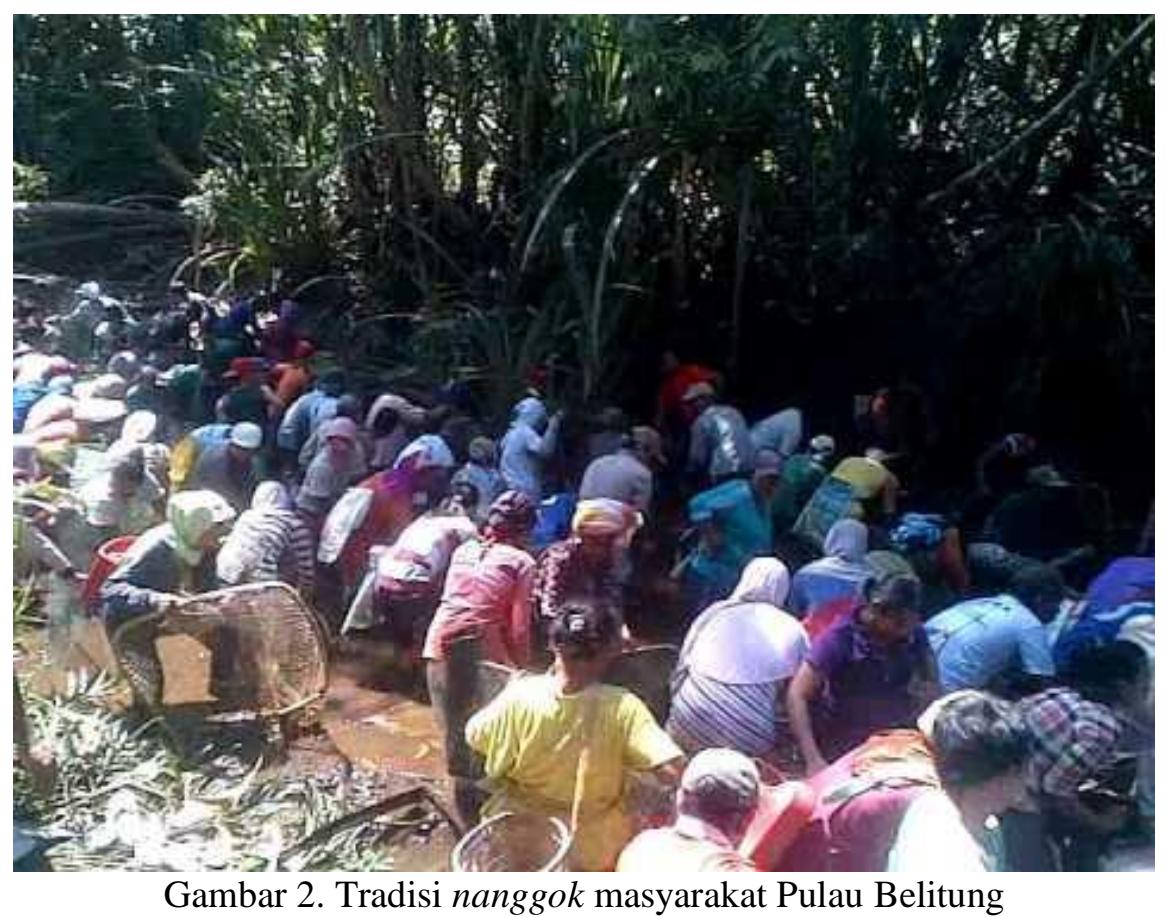

Disamping itu, juga mengatur penangkapan ikan di sungai sehingga tetap menjaga kelestarian ekosistem ikan (Heru, 2011). Selain adat di daerah tersebut, tradisi ini juga merupakan wujud kearifan lokal yang memuat kaidah matematis.

\section{Kaidah Matematis dalam Tradisi Nirok-Nanggok}

Selain sebagai wujud kearifan lokal dan hasil peninggalan bersejarah, ada tradisi budaya yang juga memuat kaidah matematis. Artinya, unsur-unsur matematis terkandung dalam tradisi budaya telah tersirat dan kasat mata sehingga masyarakat sendiri kurang menyadari keberadaan kaidah tersebut (Atmaja, 2014; Rakhmawati, 2016; Tandililing, 2016; Ubayanti, dkk., 2016). Karena masyarakat belum menyadari sehingga kaidah matematis yang kontekstual ini belum banyak mendapat kesempatan untuk dikaji (Atmaja, 2014). Selain itu, karena wilayah Indonesia terdiri dari banyak pulau-pulau, maka budaya masing-masing pulau juga memiliki perbedaan, sehingga Indonesia kaya akan budaya etnomatematika (Ubayanti, dkk., 2016; Nisafani, dkk., 2014). 
Nirok-nanggok adalah salah satu tradisi masyarakat Pulau Belitung yang memuat etnomatematika. Berdasarkan ketentuan tradisi nirok-nanggok, disimpulkan bahwa tidak ada seorang peserta yang mengetahui letak keberadaan ikan, karena kondisi air yang keruh berwarna gelap dan bercampur lumpur. Dengan tirok dan tanggok mereka penuh harapan untuk mendapatkan dan mengangkat ikan dari air, sehingga obyek kajian tradisi niroknanggok dan kaitannya dengan kaidah dalam dunia pendidikan matematika adalah pada konsep teori peluang atau biasa dikenal dengan probability, karena harapan merupakan salah satu pokok kajian dalam teori peluang. Harapan adalah suatu kemungkinan kejadian yang tidak dapat dipastikan (Yunarti, 2014).

Peluang adalah kesempatan terjadi atau kemungkinan terjadinya suatu kejadian (Yunarti, 2014; Raharjo, 2008). Kemungkinan kejadian dapat dianalisis dengan hitungan angka matematis. Dengan kata lain, bahwa peluang kejadian dapat diangkakan dengan perhitungan rasional. Dalam ilmu matematika, semuanya telah lengkap terkonsep perhitungan peluang untuk suatu kejadian. Ilmu dan teori ini dapat dijadikan alasan dasar dalam menentukan salah satu dari beberapa pilihan, sehingga akan lebih condong pada suatu pilihan yang bersesuaian dan besar kemungkinan akan terjadi.

Peluang adalah persentase suatu kejadian, atau seberapa persen suatu kejadian akan terjadi (frekuensi relatif), atau seberapa besar harapan terjadi suatu kejadian. Peluang adalah angka yang menyatakan banyak kejadian pada beberapa percobaan. Menurut bahasan dalam kajian teori peluang, bahwa peluang suatu kejadian $A$ (dilambangkan dengan $P(A)$ ), adalah banyaknya kejadian $A$ yang terjadi $(n(A))$ dibagi dengan jumlah seluruh anggota kejadian $(n(S))$. Secara singkat ditulis $P(A)=\frac{n(A)}{n(S)}$ (Raharjo, 2008).

Kontekstual konsep teori peluang yang tersirat pada tradisi nirok-nanggok, berikut beberapa contoh konsep dan maknanya.

1. Setiap warga yang ikut tradisi mendapat 12 ikan dalam 120 kali menghujamkan tirok atau menggayungkan tanggok. Artinya, jumlah percoban sebanyak 120 kali maka $n(S)=120$, dan jumlah kejadian seseorang mendapat ikan adalah 12 ikan maka $n(A)=12$, sehingga peluang setiap warga mendapat ikan $P(A)=\frac{n(A)}{n(S)}=\frac{12}{120}$.

2. Apabila jumlah seluruh warga yang ikut serta dalam tradisi nirok-nanggok sebanyak 50 orang, maka peluang seseorang mendapat ikan adalah 1/50 atau setara dengan $2 \%$. Artinya harapan seseorang mendapat ikan hanya $2 \%$. 
3. Dalam tradisi nirok-nanggok terdapat 20 orang, maka peluang seseorang mendapat ikan adalah $1 / 20$ atau 5\%. Jadi harapan seseorang mendapat ikan hanya sebesar 5\%.

Contoh 1 merupakan peluang kejadian seorang mendapat ikan dalam beberapa kali percobaan nirok-nanggok. Sedangkan contoh 2 dan contoh 3 adalah peluang seorang mendapat ikan dalam sejumlah orang yang ikut serta acara tradisi. Dengan demikian, disimpulkan bahwa semakin sering warga menghujamkan tirok atau menggayungkan tanggok maka jelas akan semakin banyak mendapat ikan, dan semakin banyak warga yang ikut serta dalam tradisi nirok-nanggok maka semakin kecil pula kemungkinan setiap peserta akan merasakan kicauan ikan pada ujung besi tirok atau dalam jala tanggok.

Contoh lain yang merupakan teori peluang dapat disajikan dengan kasus berbeda, konsep kasusnya dinamakan dengan peluang kejadian independen atau biasa dikenal dengan mutually independent $(P(A \cap B))$. Dikatakan independen karena peluang setiap warga mendapat ikan dalam beberapa kali percobaan $(P(A))$, berbeda dengan peluang seorang mendapat ikan dalam sejumlah peserta tradisi $(P(B))$, kedua peluang ini tidak terkait satu sama lain. Ketidakterkaitan inilah menjadi dasar penamaan independen. Dalam teori peluang, dirumuskan peluang kejadian independen $P(A \cap B)=P(A) \times P(B)$ (s).

Kasus demikian bisa juga dikatakan sebagai konsep peluang bersyarat atau conditional probability, karena peluang seseorang mendapat ikan $(P(A \cap B))$ dalam jumlah peserta sebanyak 50 orang $(P(A))$, dengan syarat bahwa setiap warga dalam tradisi mendapat 12 ikan dalam 120 kali percobaan $(P(A \mid B))$. Dalam teori peluang, peluang kejadian bersyarat diformulasikan dengan $P(A \mid B)=\frac{P(A \cap B)}{P(A)}$ atau sama juga dengan bentuk peluang kejadian independen $P(A \cap B)=P(A \mid B) \times P(A)$.

Contohnya, setiap warga mendapat 12 ikan dalam 120 kali menghujamkan tirok atau menggayungkan tanggok masing-masing, dalam jumlah peserta tradisi sebanyak 50 orang, sehingga nilai angka peluang kejadian bahwa warga tersebut akan mendapat ikan adalah $P(A \cap B)=P(A \mid B) \times P(A)=\frac{12}{120} \times \frac{1}{50}=\frac{1}{500}$. Dengan demikian, dapat diformulasikan bahwa peluang seseorang akan mendapatkan ikan, dengan jumlah peserta sebanyak $n$ orang, apabila setiap warga mendapat $x$ ikan dalam $p$ kali percobaan adalah $P(A)=\frac{x}{p} \times \frac{1}{n}=\frac{x}{n p}$. 
Konsep teori peluang lain dicontohkan seperti berikut: misal dalam suatu lembong (genangan) sungai terdapat ikan sebanyak 500 ekor, dan warga yang ikut acara tradisi sebanyak 20 orang, sehingga harapan tiap peserta akan mendapat ikan sebanyak 25 ekor. Angka 25 ekor ikan tersebut adalah hasil bagian merata 500 ekor ikan kepada 20 orang, sehingga tiap peserta mendapat 25 ekor. Pembagian tersebut merata karena tiap peserta tradisi memiliki peluang yang sama untuk mendapat ikan. Konsep demikian adalah frekuensi harapan dalam teori peluang. Frekuesi harapan $(F H)$ adalah banyaknya jumlah kejadian yang terjadi dalam percobaan sebanyak $n$ kali. Dirumuskan $F H=P(A) \times n$ (Raharjo, 2008), sehingga frekuensi harapan tiap peserta adalah $F H=\frac{1}{20} \times 500=25$ ekor.

Tidak ada peserta yang bisa memastikan bahwa peluang seorang lebih besar dari peserta lain, karena alat yang digunakan sama-sama kelompok tirok atau tanggok. Penentuan besarnya peluang untuk mendapat ikan hanya banyaknya jumlah percobaan yang dilakukan. Sedangkan pengetahuan tentang bagaimana dan dimana tempat keberadaan ikan dalam air adalah bagian kemahiran pribadi dan kondisi ini bisa diabaikan karena setiap peserta berasal dari daerah setempat, sehingga pengetahuan telah termiliki alami dan bukan suatu yang asing lagi.

Demikian kajian tentang kaidah matematis pada tradisi nirok-nanggok masyarakat pulau Belitung. Teori peluang merupakan teori yang hanya memprediksi bukan memberi suatu kepastian. sehingga teori ini tidak lepas dari kata-kata harapan atau peluang, dengan maksud bahwa suatu kejadian mungkin akan terjadi dan mungkin juga tidak terjadi. Hasil kajian ini mengindikasikan bahwa para leluhur yang hidup zaman dahulu di tanah Belitung merepresetasikan kaidah matematis tertentu dalam acara-acara tradisional yang sakral.

\section{KESIMPULAN}

Nirok-nanggok adalah salah satu acara tradisi masyarakat di Pulau Belitung yang memuat kaidah matematis. Nirok-nanggok berasal dari nama alat yang digunakan yaitu tirok dan tanggok. Dengan tirok dan tanggok, warga yang menjadi peserta tradisi menaruh harapan untuk mendapatkan dan mengangkat ikan dari air, sehingga kaidah matematis ynag dimuat tradisi ini adalah teori peluang. Beberapa contoh kontekstual konsep teori peluang dalam tradisi adalah peluang kejadian independen, peluang kejadian bersyarat, dan frekuensi harapan. Manfaat teori peluang adalah sebagai dasar penentuan salah satu dari beberapa pilihan, sehingga pemilih terhindar dari pilihan yang salah atau tidak mungkin 
terjadi. Contoh dalam acara tradisi seperti menghujamkan tirok atau menggayungkan tanggok di lembong yang diperkirakan tidak mungkin ada ikannya.

\section{REKOMENDASI}

Berdasarkan simpulan hasil kajian di atas, maka rekomendasi yang dapat disampaikan adalah agar cakupan contoh kontekstual suatu kajian tradisi lebih diperluas. Selain kaidah matematis yang tersirat dalam suatu tradisi termaknai lebih detail dan jelas, adanya keterkaitan pada beberapa konsep matematis lain juga mungkin ditemukan apabila dipandang dari suatu sudut pandang tertentu, dan kemudian bisa dibuatkan kontekstual konsepnya. Lebih lanjut, pendalaman kajian juga sangat mungkin dilakukan untuk melengkapi kekurangan dan keterbatasan yang belum terpikirkan dalam kajian.

\section{REFERENSI}

Adjin, A. H., Salim Y.A.H., \& Sahib, R. (2014). Sejarah Perjuangan Rakyat Belitung (1924-1950). Bangka Belitung : Kantor Kerasipan dan Perpustakaan Kabupaten Belitung.

Atmaja, I.M.D. (2014). Ethnomatematika Pencipta Lagu dan Kaitannya dengan Materi Pembelajaran Matematika. Jurnal Santiaji Pendidikan, 4(1), 1-14.

Bamboe. (2011, Oktober 1). Belitung Tour Guide: Belitong. Diperoleh dari http://belitungtourguide.blogspot.co.id/.

Edgina, N. (2015, September 10). Nanggok. Diperoleh dari goo.gl/uMcwnr.

Heru. (2011). Nirok dan Nanggok. Diperoleh dari http://jelajahbelitung.com/2011/06/05/nirok-nanggok/ (2017, Maret 17).

Nisafani, A. S., Muqtadiroh, F. A., \& Nugraha, N. F. (2014). Analisis dan Perancangan WikiBudaya dalam Rangka Melestarikan Budaya Bangsa dan Kearifan Lokal Nusantara. Jurnal SISFO, 5(2), 146-158.

Wikipedia. (2017). Pulau Belitung. Diperoleh dari https://id.wikipedia.org/wiki/Pulau_Belitung (2017, Maret 17).

Prambudi, I. (2010). Perubahan Mata Pencaharian dan Nilai Sosial Budaya Masyarakat (Studi Deskriptif Kualitatif Tentang Hubungan Perubahan Mata Pencaharian Dengan Nilai Sosial Budaya Masyarakat di Desa Membalong, Kecamatan Membalong, Belitung). (Doctoral dissertation, Universitas Sebelas Maret).

Rachman, M. (2012). Konservasi Nilai dan Warisan Budaya. Indonesian Journal of Conservation, 1(1), 30-39.

Raharjo, M. (2008). Pembelajaran Peluang SMA. Yogyakarta: DEPDIKNAS.

Rakhmawati, M.R. (2016). Aktivitas Matematika Berbasis Budaya pada Masyarakat Lampung. Jurnal Pendidikan Matematika, VII(2), 131-144.

Tandililing, P. (2016). Etnomatematika Toraja (Eksplorasi Geometris Budaya Toraja). Jurnal Ilmiah Matematika dan Pembelajarannya, 1(1), 37-46.

Triwardani, R., \& Rochayanti, C. (2014). Implementasi Kebijakan Desa Budaya dalam Upaya Pelestarian Budaya Lokal. Reformasi, 4(2). 102-110. 
Ubayanti, C. S., Lumbantobing, H., \& Manurung, M. M. (2016). Eksplorasi Etnomatematika pada Sero (Set Net): Budaya Masyarakat Kokas Fakfak Papua Barat. Jurnal Ilmiah Matematika dan Pembelajarannya, 2(1), 11-17.

Yunarti, T. (2014). Desain Didaktis Teori Peluang SMA. Jurnal Pendidikan MIPA, 15(1). 15-20. 
